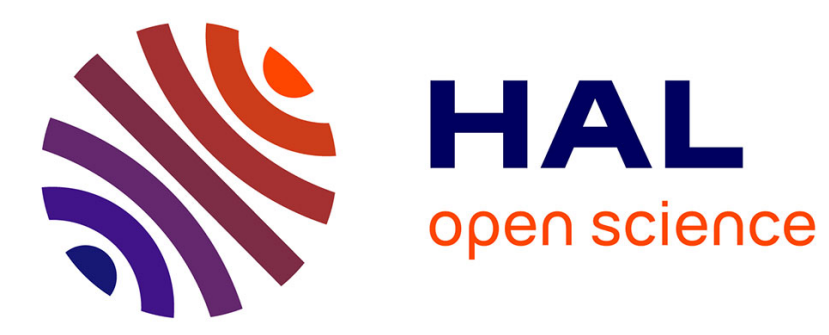

\title{
Primary neurolymphomatosis diagnosis and treatment: A retrospective study
}

Stanislas Lagarde, E. Tabouret, M. Matta, J. Franques, S. Attarian, J. Pouget, A. Maues de Paula, D. Figarella-Branger, P. Dory-Lautrec, O. Chinot, et al.

\section{To cite this version:}

Stanislas Lagarde, E. Tabouret, M. Matta, J. Franques, S. Attarian, et al.. Primary neurolymphomatosis diagnosis and treatment: A retrospective study. Journal of the Neurological Sciences, 2014, 342 (1-2), pp.178-181. 10.1016/j.jns.2014.04.030 . hal-01851643

\section{HAL Id: hal-01851643 https://hal.science/hal-01851643}

Submitted on 21 Mar 2020

HAL is a multi-disciplinary open access archive for the deposit and dissemination of scientific research documents, whether they are published or not. The documents may come from teaching and research institutions in France or abroad, or from public or private research centers.
L'archive ouverte pluridisciplinaire HAL, est destinée au dépôt et à la diffusion de documents scientifiques de niveau recherche, publiés ou non, émanant des établissements d'enseignement et de recherche français ou étrangers, des laboratoires publics ou privés. 


\section{Clinical Short Communication:}

Primary Neurolymphomatosis diagnosis and treatment: a retrospective study

Authors: S. Lagarde ${ }^{1}$, E. Tabouret ${ }^{1}$, M. Matta ${ }^{1}$, J. Franques ${ }^{2}$, S. Attarian ${ }^{2}$, J.Pouget ${ }^{2}$, A. Maues

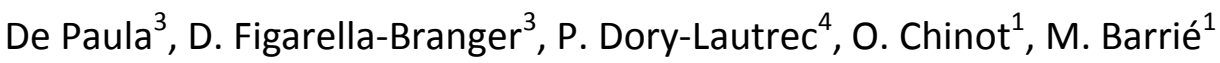

1- Service de Neuro-Oncologie, CHU La Timone, Assistance publique-Hôpitaux de Marseille, 264, rue St-Pierre, 13005 Marseille

2- Centre de Référence des Maladies Neuromusculaires et de la SLA, CHU La Timone, Assistance publique-Hôpitaux de Marseille, 264, rue St-Pierre, 13005 Marseille

3- Service d'anatomie pathologique et de neuropathologie, CHU La Timone, Assistance publique-Hôpitaux de Marseille, 264, rue St-Pierre, 13005 Marseille

4- Service de neuroradiologie diagnostique et interventionnelle, CHU La Timone, Assistance publique-Hôpitaux de Marseille, 264, rue St-Pierre, 13005 Marseille

Corresponding author: Stanislas Lagarde; Service de Neuro-Oncologie, CHU La Timone, Assistance publique-Hôpitaux de Marseille, 264, rue St-Pierre, 13005 Marseille, France; Telephone number: +33491385500 ; Fax number: +33491387348 ; Electronic adress: stanislas.lagarde@ap-hm.fr 


\section{ABSTRACT}

Background: To discuss the therapeutic approach for primary neurolymphomatosis.

Methods: We report all primary neurolymphomatosis cases referred to our institution, with descriptions of clinical, radiological, electrophysiological, histological features and long-term follow-up. We treated all patients with a combination of high-dose methotrexate and alkylating agents.

Results: Five patients were diagnosed with histologically confirmed primary neurolymphomatosis. The majority of them presented with painful asymmetric sensorymotor neuropathy. Magnetic resonance imaging was abnormal in 4 of 5 patients, as shown with gadolinium enhancements. Electroneuromyography revealed denervation in all 4 cases with contributive examinations. All our patients received a chemotherapy combination of high-dose methotrexate and alkylating agent. Median progression-free survival was of 8 months ( 2 complete responses and 2 partial responses), and overall survival was 24 months.

Conclusions: Primary neurolymphomatosis is rare and polymorphic; they represent a difficult diagnosis of neuropathy. In our cohort, treatment with a chemotherapy combination with high-dose methotrexate showed encouraging results.

Key Words: lymphoma, neurolymphomatosis, peripheral nervous system, electroneuromyography, MRI, chemotherapy 


\section{INTRODUCTION}

Neurolymphomatosis (NL) is a rare and severe affliction of peripheral nervous system (PNS). This disorder is defined as direct nervous infiltration by lymphomatous cells ${ }^{1}$. NL should be distinguished from other neurological complications of lymphoma; for example, mechanical compression, paraneoplastic syndrome, gammapathy (including anti-MAG neuropathy) or side-effects of treatment ${ }^{2-3}$. Clinical presentations vary and include sensory or/and motor impairment, with or without neuropathic pain. All parts of the PNS (plexus, roots and nerves, including cranial roots) can be affected ${ }^{4}$. While the vast majority of NL is secondary to a systemic disease or a primary central nervous system (CNS) lymphoma, primary NL (PNL) consists of isolated nervous involvement by lymphoma cells. PNL has been only incidentally reported $^{4-9}$. Consequently, the diagnosis of PNL is challenging and its evolution poorly documented. Whether PNL should be treated as systemic lymphoma utilizing a rituximabcyclophosphamide-doxorubicine-vincristine regimen or as primary CNS lymphoma (PCNSL) using high-dose methotrexate- (MTX) based regimen is unclear. We report 5 cases of PNL referred to our institution to discuss our therapeutic strategy and performed a comprehensive review of the literature.

\section{METHODS}

We performed a retrospective analysis of all patients referred to our department of NeuroOncology (AP-HM, Timone Hospital, Marseille, France) for PNL from August 2000 to May 2012. A total of 117 patients with primary lymphoma of the nervous system (central or peripheral) were referred during this period. All patients had histological confirmation of their PNL diagnosis. Through CNS Magnetic Resonance Imaging (MRI), Body-Computed Tomography (CT), Body-PET-FDG, ophthalmologic examination, and bone marrow aspiration 
and biopsy we excluded systemic or CNS lesions. The following data were collected: initial presentation, delay between first symptoms and treatment initiation, neurological examination, performance index (KPS), blood tests, neuro-imaging features, cerebrospinal fluid (CSF) analysis, nerve/roots biopsy analysis, treatment modalities, and long-term followup. Progression-free survival (PFS) was defined as the time from the PNL diagnosis to progression or death. Overall survival (OS) was defined as the time from the PNL diagnosis to the death from any cause, censored at the date of last contact.

\section{RESULTS}

Five patients were identified, including 4 men and one woman, with the median age at diagnosis being 65 years (range: $53-77)$. None of patients had previous comorbidity. Median Karnovsky Performance Score (KPS) at diagnosis was 70\% (range: 60\%-70\%). All cases reported sensory and motor impairments, and 3 of them suffered from neuropathic pain. Initial symptoms involved plexus ( 2 cases), lumbar roots ( 2 cases) and cauda equina (1 case). Median time from initial symptom to first neurological examination was 3 months (range, 16 months). Median time from first symptoms to diagnosis was 10 months (range, 2-18 months)

Electroneuromyography revealed axonal damage in all 4 cases with contributive examinations; and demyelinating and axonal damages coexisted in one case. Magnetic resonance imaging was abnormal in 4 of 5 patients, with gadolinium enhancements of cranial nerves (1 case), cauda equina (1 case with multiple lesions), S1 left root (1 case) and cervical left plexus (1 case) as shown in Figure 1. CSF analysis showed high protein levels (range between 1.3 to $5 \mathrm{~g} / \mathrm{l}$ ) in all 5 cases but failed to identify lymphomatous cells in 3 cases. 
Confirmation of diagnosis was based on biopsy of lesion (3 patients) or CSF examination (2 patients). In all cases, histology or cytology showed large B lymphomatous cells. Biopsies were performed on the pathological area determined by clinical examination, electroneuromyography, MRI (2 patients) and PET-FDG (hypermetabolism in 1 patient). Biopsies concerned the sural nerve in one patient, $L 4$ roots in another, and cauda equina roots in the last one. The sural nerve biopsy showed a perivascular lymphomatous infiltration and a consequent axonal degeneration as shown in Figure 2. The 2 other biopsies did not enable a leptomeningeal to be distinguished from a hematogenous process. However, at relapse, one patient with prove of lymphomatous infiltration in biopsy showed a positive CSF cytology arguing in favor of leptomeningeal dissemination.

All patients were treated with poly-chemotherapy using high-dose MTX and alkylating agent (Table 1). Secondary to a lack of standardized response criteria, we based our evaluation on clinical and radiological features. Two patients experienced a complete response, and 2 patients experienced partial responses with treatment being well tolerated in all cases. At relapse, 3 patients received intrathecal cytarabine. In one case, we also used a R-CHOP protocol (rituximab, cyclophosphamide, doxorubicin, vincristine, and prednisone). During initial treatment one patient benefited from MTX intrathecal injection because of clinical and radiological progression after the first evaluation; however, he did not respond to the next treatment (lomustine \& procarbazine). He died 2.8 months after the initiation of treatment. At the last contact, 2 patients were alive without relapse. Median follow-up was 26 months, median PFS was 8 months $(\mathrm{Cl} 95 \%=1.6-14.4)$ and median OS was 24 months $(\mathrm{Cl} 95 \%=$ 17.6-30.4). PFS and OS of patients with CSF lymphomatous cells were not statistically different but median OS was numerically worse for these patients (13.7 vs. 36.8 months). However, it should be noted that one of them did not respond to any treatment, leading to 
an unfavorable outcome. Median PFSs were close in the 2 groups (12 vs. 13.5 months). No patient developed systemic involvement and topographies of recurrence were PNS (for 2 patients) and CNS (for 1 patient).

\section{DISCUSSION}

The interactions between lymphoma and the PNS are multiple and include mechanical compression, paraneoplastic syndrome, treatment side-effect, or tumoral infiltration by lymphomatous cells ${ }^{2}$. Previous reports on PNL have been restricted to case reports or mixed with secondary NL literature ${ }^{4,6-9}$. We reported 5 cases of PNL, which have to be distinguished from secondary infiltration by systemic lymphoma. In our study, we investigated only patients who presented with primary and isolated lymphomatous infiltration of peripheral nerves without systemic or cerebral involvement.

PNL remains a very rare entity. One hundred and eighty-one patients with NL were reported in the literature with 22 cases of well-defined primary $\mathrm{NL}^{4,6-9}$ that were essentially case reports, with the exception of Baehring, Grisariu and Tomita's publications ${ }^{1,10-11}$. Recently, the International Primary CNS Lymphoma Collaborative Group retrospectively analyzed 50 patients with $\mathrm{NL}^{10}$. However, in this recent publication, PNL represented only 4 cases, underlining the diagnostic complexity and the specificity of this syndrome. In 2013 Tomita published a retrospective study of 15 NL cases including 6 PNL cases with proven histology $(\text { CSF or biopsy) })^{11}$. Nevertheless, their therapeutic strategies remained inhomogeneous and only one PNL of this cohort benefited from systemic MTX treatment. In this context, we described a homogenous cohort of PNL with common treatment based on high-dose MTX and alkylating agent. 
Initial presentations were in line with those reported in the literature with progressive asymmetric sensory-motor painful neuropathy. However, motor or sensory impairment could be isolated as the first symptom of PNL, leading to diagnostic uncertainty. Topography of infiltration was mostly extended, multifocal and asymmetric (nerve, plexus or root involvement). PNL diagnosis remains challenging and requires evidence of nervous infiltration (plexus or root MRI, PET-FDG) with histological characterization. Long delays between the first symptoms and the diagnosis were observed in our cohort, underlining the difficulty in PNL diagnosis. Evolution of NL is heterogeneous, with OS ranging between 1 to 372 months $^{4}$ with a median OS of 10 months $^{10}$.

The physiopathology of lymphocytic monoclonal proliferation isolated in the PNS remains unclear. Two alternative mechanisms have been suggested: proliferation of B cell precursors primarily localized in the PNS or systemic cells crossing through blood-nerve/CSF-nerve barrier $^{7}$. The blood-nerve barrier is a complex interface composed of endothelium, endoneurial and perineurial stroma ${ }^{12}$. Tomita's study showed preferential invasion by lymphomatous cells of the perineurium ${ }^{11}$. The pathological lymphocyte crossing was hypothesized to be permissible by the aberrant expression of NCAM by lymphomatous B cells that bind with the CD56, supported by neural cells ${ }^{5}$. Histological presentation supported a potential hematogenous dissemination in one case (with endoneurial infiltration in sural nerve biopsy) and meningeal infiltration in 2 other cases (CSF positivity). In contrast, we did not find arguments to support local lymphomatous proliferation. Clinical evolution according to physiopathology remained unclear, since we did not find any difference in terms of OS or PFS between patients with CSF infiltration by lymphomatous cells and others. However, as our cohort remained a very small population, results should be cautiously interpreted. 
Optimal management of PNL remains to be defined. A literature review of isolated case reports revealed heterogeneous treatment regimens including tumor resection ${ }^{9,13}$, irradiation ${ }^{5,6,13,14}$ and poly-chemotherapies usually applied in systemic lymphoma treatment $(\mathrm{R} \text {-CHOP regimen })^{5,7,8}$. Radiation therapy can be provided for curative or palliation intent. It is unclear whether the latter adds benefit in combination with systemic chemotherapy but some authors have reported excellent local control in patients with localized disease (mononeuropathy) $)^{4}$

Since the association of high-dose MTX and alkylating agent was well known for a good diffusion across the blood-brain barrier, we expected similar diffusion across the bloodnerve barrier. Moreover, since our PNL cases showed PNS extended infiltration without systemic dissemination, we hypothesized a potential similar physiopathology with primary CNS lymphoma. We therefore used poly-chemotherapy based on high-dose MTX and alkylating agent ${ }^{14}$ by homology of primary CNS lymphoma treatment. Although our cohort remained small, PFS and OS were longer than those reported in the literature ${ }^{1,4,5,7,10}$ with an OS over 2 years in 3 out of 5 cases, suggesting an interesting activity of MTX-based combination in treatment of PNL. In addition, based on its activity documented in systemic lymphoma, rituximab could be an attractive agent when used in combination with MTX, although its diffusion in the CNS remains unknown ${ }^{15}$. Finally, intensive chemotherapy followed by autologous hematopoietic stem-cell transplantation could be an interesting option for refractory or recurrent PNL.

\section{CONCLUSION}

In conclusion, we have presented a homogenous retrospective cohort of PNL as confirmed by histology. Clinical presentations were varied with a predominance of multiple 
sensory-motor and painful neuropathies. Optimal treatment of PNL remains to be determined but high-dose MTX-based poly-chemotherapy was associated with encouraging results in our small cohort. Further studies are needed to confirm the benefit of this potential therapeutic strategy. 
Table 1 - Summary of Patients features

\begin{tabular}{|c|c|c|c|c|c|}
\hline Patient & 1 & 2 & 3 & 4 & 5 \\
\hline Gender/Age & $\mathrm{M} / 65$ & $\mathrm{M} / 55$ & $\mathrm{M} / 53$ & $F / 68$ & $\mathrm{M} / 73$ \\
\hline $\begin{array}{l}\text { Initial Site } \\
\text { Involved }\end{array}$ & $\begin{array}{l}\text { Lombar } \\
\text { plexus }\end{array}$ & $\begin{array}{c}\text { Lombosacral left } \\
\text { roots }\end{array}$ & $\begin{array}{l}\text { Cervical } \\
\text { Plexus }\end{array}$ & $\begin{array}{l}\text { Equina } \\
\text { Cauda }\end{array}$ & S1 right root \\
\hline $\begin{array}{c}\text { Diagnosis } \\
\text { Delay* }\end{array}$ & 12 & 10 & 22 & 4 & 2 \\
\hline $\begin{array}{c}\text { CSF } \\
\text { (protein rate/ } \\
\text { cytology) }\end{array}$ & $\begin{array}{c}1.3 / \\
\text { Lymphoma } \\
\text { cells }\end{array}$ & $\begin{array}{c}5 \text { / Pleiocytosis } \\
\text { (initially) } \\
\text { Lymphoma Cells } \\
\text { (at relapse) }\end{array}$ & $\begin{array}{l}4.5 / \\
\text { Lymphoma } \\
\text { Cells }\end{array}$ & 1.3 / O cell & $\begin{array}{c}1.3 \text { / } \\
\text { Pleiocytosis }\end{array}$ \\
\hline $\begin{array}{c}\text { Nervous } \\
\text { biopsy } \\
\text { (site / result) }\end{array}$ & $\begin{array}{l}\text { Sural / } \\
\text { Normal }\end{array}$ & $\begin{array}{l}\text { Equina Cauda / } \\
\text { Lymphoma Cells }\end{array}$ & Not Realized & $\begin{array}{c}\text { Sural / } \\
\text { Lymphoma } \\
\text { Cells }\end{array}$ & $\begin{array}{l}\text { L4 roots / } \\
\text { Lymphoma } \\
\text { Cells }\end{array}$ \\
\hline $\begin{array}{l}\text { First line } \\
\text { Treatment }\end{array}$ & $\begin{array}{c}\mathrm{MTX} 3 \mathrm{~g} / \mathrm{m}^{2}, \\
\mathrm{TMZ} \\
200 \mathrm{mg} / \mathrm{m}^{2}\end{array}$ & $\begin{array}{c}\text { MTX 3g/m² } \\
\text { TMZ 200mg/m }{ }^{2}\end{array}$ & $\begin{array}{c}\mathrm{MTX} 3 \mathrm{~g} / \mathrm{m}^{2} \\
+\mathrm{CCNU} \\
80 \mathrm{mg} / \mathrm{m}^{2} \\
+ \\
\text { Procarbazine } \\
100 \mathrm{mg} / \mathrm{m}^{2}\end{array}$ & $\begin{array}{c}\mathrm{MTX} 1 \mathrm{~g} / \mathrm{m}^{2} \\
\mathrm{TMZ} \\
100 \mathrm{mg} / \mathrm{m}^{2}\end{array}$ & $\begin{array}{c}\mathrm{MTX} 3 \mathrm{~g} / \mathrm{m}^{2} \\
\mathrm{TMZ} \\
200 \mathrm{mg} / \mathrm{m}^{2}\end{array}$ \\
\hline PFS* & 24.5 & 1.5 & 1 & 33 & 6 \\
\hline $\begin{array}{l}\text { Site of } \\
\text { relapse }\end{array}$ & No relapse & $\begin{array}{c}\text { Controlateral } \\
\text { lombo-sacral } \\
\text { roots }\end{array}$ & $\begin{array}{l}\text { Lack of } \\
\text { response }\end{array}$ & No relapse & CNS (cerebral) \\
\hline $\begin{array}{l}\text { Second line } \\
\text { treatment }\end{array}$ & Inexistant & $\begin{array}{c}\mathrm{R}-\mathrm{CHOP}+ \\
\text { Cytarabine IT }\end{array}$ & Cytarabine IT & Inexistant & $\begin{array}{c}\text { MTX + } \\
\text { Cytarabine IT }\end{array}$ \\
\hline OS* & 24.5 & 21.2 & 2.8 & 33 & 56.2 \\
\hline
\end{tabular}

KPS = Karnovsky Performance Status; PFS = Progression-Free Survival; OS = Overall Survival; * = months ; $\mathrm{MTX}=$ methotrexate; $\mathrm{TMZ}=$ temozolomide; $\mathrm{R}-\mathrm{CHOP}=$ rituximab + cyclophosphamide + doxorubicin + vincristine + prednisone ; IT = intra-thecal; Diagnosis Delay: time from first symptom to diagnosis ; Age in years ; CSF protein rate in $\mathrm{g} / \mathrm{l}$ 
Figure 1: Brachial plexus MRI of patient 3 in T2 sequence and transversal incidence. Hyper signal and thickening of plexus trunks (arrowheads in A \& B) suggesting infiltration of left brachial plexus.
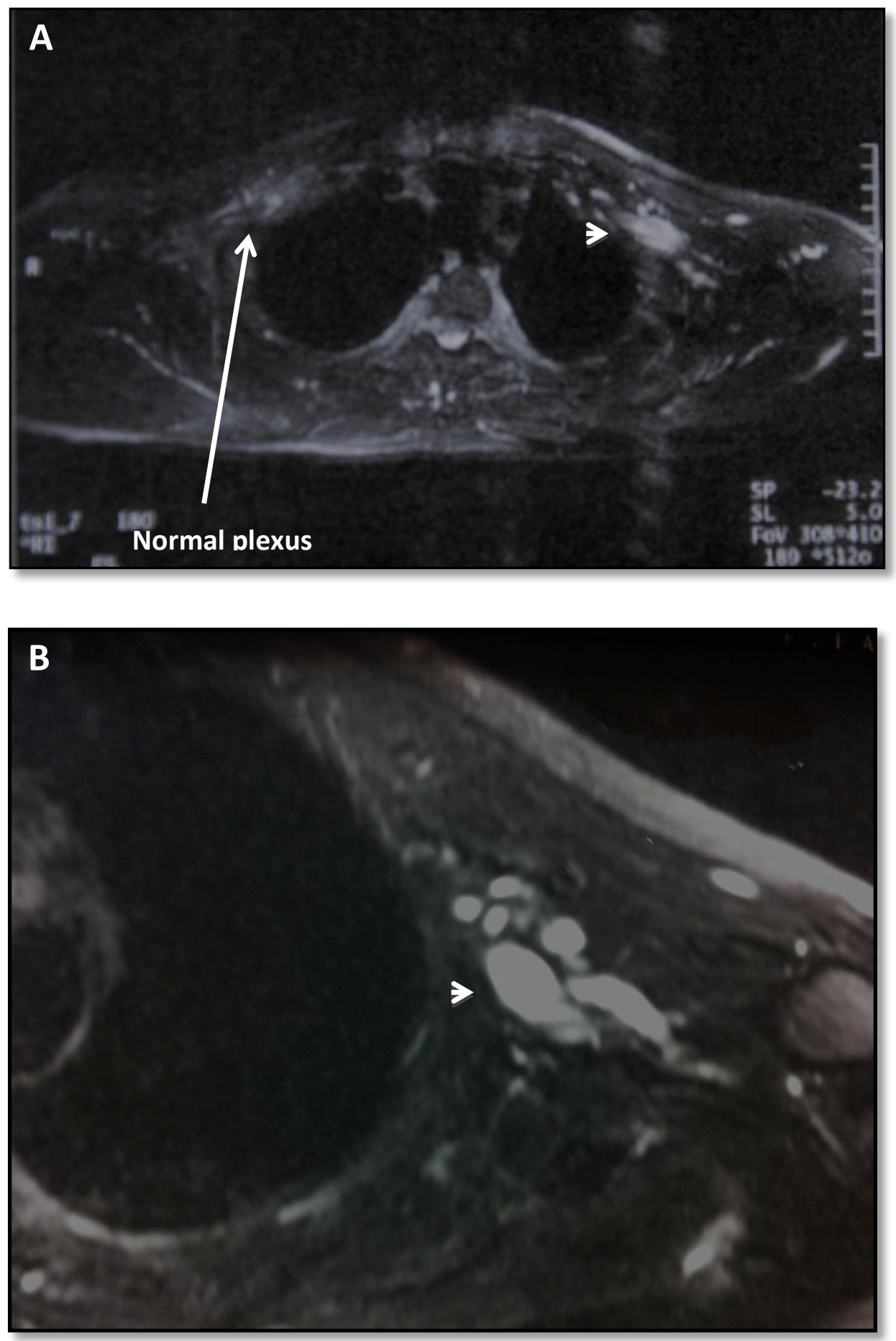
Figure 2: Sural nerve biopsy of patient 5. A) Perivascular mononuclear lymphocytic cells around a small vessel. Their pleomorphic and hyperchromatic nuclei suggest their lymphomatous nature (hematoxylin-eosin X 200). B) Severe loss of nerve fibers and many degenerated axons (arrow heads) are seen with special stain (PPD X 100).
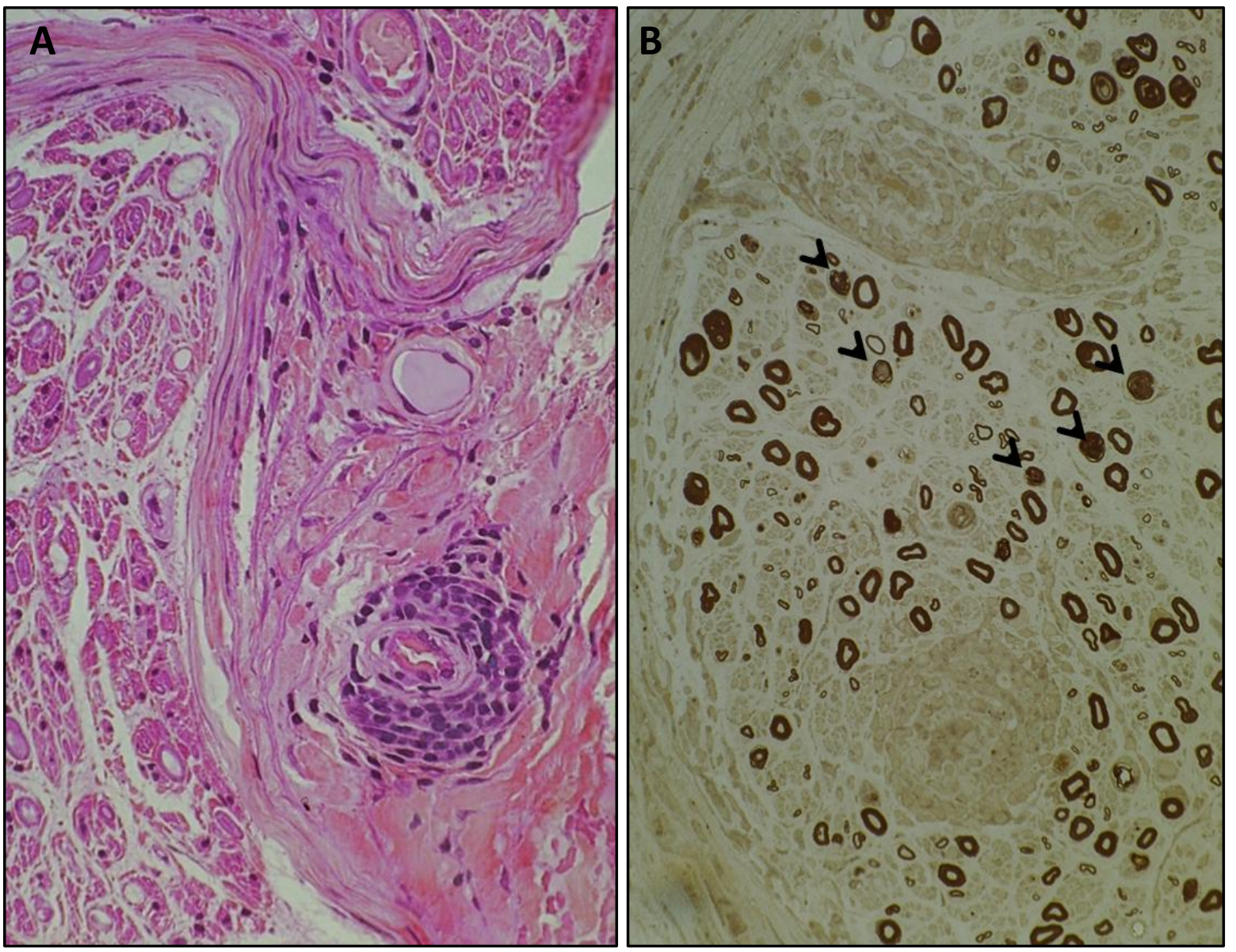
Supplementary table: Literature review of all reported cases of Primary Neurolymphomatosis.

\begin{tabular}{|c|c|c|c|c|c|c|c|c|c|}
\hline Authors & Years & $\begin{array}{c}\text { Number } \\
\text { of } \\
\text { patients }\end{array}$ & $\begin{array}{c}\text { Number } \\
\text { of PNL }\end{array}$ & Clinic & Diagnosis & CSF & Imaging & Treatment & OS \\
\hline Pillay & 1988 & 1 & 1 & $\begin{array}{l}\text { Motor \& } \\
\text { pain }\end{array}$ & Histology & Unknown & 1 & RTH & 12 \\
\hline Eusebi & 1990 & 1 & 1 & $\begin{array}{l}\text { Sensory- } \\
\text { motor }\end{array}$ & Histology & Unknown & Unknown & $\begin{array}{c}\text { Resection } \\
\text { RTH }\end{array}$ & 16 \\
\hline Kanamory & 1995 & 1 & 1 & Unknown & Histology & Unknown & 1 & CTX RTH & 30 \\
\hline Kim & 1998 & 1 & 1 & $\begin{array}{l}\text { Sensitive } \\
\text { only }\end{array}$ & Histology & 0 & 0 & RTH & 24 \\
\hline Misdraji & 2000 & 4 & 4 & $\begin{array}{l}\text { Sensory- } \\
\text { motor \& } \\
\text { pain }\end{array}$ & Histology & 0 & 0 & $\begin{array}{c}\text { R-CHOP } \\
\text { Pro-MACE } \\
\text { CytaBOM } \\
\text { RTH } \\
\text { CNOP }\end{array}$ & 40 \\
\hline Baerhing & 2003 & 25 & 2 & Unknown & CSF & 1 & 1 & Unknown & Unknown \\
\hline Pagès & 2004 & 1 & 1 & Unknown & Histology & 0 & 0 & Adria, Cyclo & 180 \\
\hline Descamps & 2006 & 1 & 1 & $\begin{array}{c}\text { Motor \& } \\
\text { pain }\end{array}$ & Histology & 1 & 1 & $\mathrm{R}-\mathrm{CHOP}$ & 48 \\
\hline Iplikcioglu & 2008 & 1 & 1 & $\begin{array}{l}\text { Sensitive } \\
\& \text { pain }\end{array}$ & Histology & 0 & 1 & $\begin{array}{c}\text { RTH MTX } \\
\text { Ara-IT }\end{array}$ & 12 \\
\hline Kahraman & 2008 & 10 & 1 & $\begin{array}{l}\text { Sensory- } \\
\text { motor \& } \\
\text { pain }\end{array}$ & Histology & 1 & 1 & $\mathrm{R}-\mathrm{CHOP}$ & 10 \\
\hline Grisaru & 2010 & 50 & 2 & Unknown & Histology & 1 & 1 & Unknown & Unknown \\
\hline Okada & 2012 & 1 & 1 & $\begin{array}{l}\text { Sensory- } \\
\text { motor }\end{array}$ & Histology & 0 & 1 & Resection & 36 \\
\hline Tomita & 2013 & 15 & 6 & $\begin{array}{l}\text { Sensory- } \\
\text { motor \& } \\
\text { pain }\end{array}$ & $\begin{array}{l}\text { Histology / } \\
\text { CSF }\end{array}$ & 4 & 2 & $\begin{array}{c}\text { R-CHOP } \\
\text { MTX }\end{array}$ & 60 \\
\hline \multicolumn{10}{|c|}{$\begin{array}{l}\mathrm{NL}=\text { neurolymphomatosis; } \mathrm{CSF}=\text { cerebro-spinal fluid; } 1=\text { positive; } 0 \text { = negative; } \mathrm{RTH}=\text { radiotherapy } ; \mathrm{R}-\mathrm{CHOP}=\text { rituximab }+ \\
\text { cyclophosphamide + doxorubicin + vincristine + prednisone; CTX = chemotherapy (protocol no described) ; Pro-MACE + } \\
\text { CytaBOM: cyclophosphamide, doxorubicin, etoposide cytozar, bleomycin, vincristine, methotrexate and prednisone ; CNOP : } \\
\text { vincristine, mitoxantrone, cyclophosphamide et prednisolone ; Cyclo= cyclophosphamide ; Adria = adriamycine }\end{array}$} \\
\hline
\end{tabular}




\section{Contributorship Statement:}

S.L and E.T conceived and designed the study, analyzed and interpreted data. S.L and E.T drafted the article. DFB analyzed sural nerve biopsy. A.MDP reviewed and created figure 2 of nerve biopsy analysis. P.D-L reviewed MRI images and created figure 1. M.M, J.F, J.P, M.B, S.A and O.C revised it critically for important intellectual content. All authors read and approved the final manuscript.

\section{Competing Interests Statement:}

All authors have nothing to disclose.

\section{Acknowledgements:}

Biopsies specimen were stored in the AP-HM tumor bank (authorization number AC 20131786)

We thank the patients association ARTC Sud who supported the financial cost of the English revision of the manuscript. 


\section{References}

1. Baehring JM, Batchelor TT. Diagnosis and management of neurolymphomatosis. Cancer J 2012; 18(5): 463-8.

2. Kelly JJ, Karcher DS. Lymphoma and peripheral neuropathy: A clinical review. Muscle a d Nerve 2005; 31(3): 301-13.

3. Viala K, Behin A, Maisonobe T, et al. Neuropathy in lymphoma: a relationship between the pattern of neuropathy, type of lymphoma and prognosis? Journal of Neurology, Neurosurgery \& Psychiatry 2008; 79(7): 778-82.

4. Baehring JM, Damek D, Martin EC, Betensky RA, Hochberg FH. Neurolymphomatosis. Neuro Oncol 2003; 5(2): 104-15.

5. Misdraji J, Ino Y, Louis DN, Rosenberg AE, Chiocca EA, Harris NL. Primary lymphoma of peripheral nerve: report of four cases. Am J Surg Pathol 2000; 24(9): 1257-65.

6. Iplikcioglu AC, Dinc C, Bikmaz K, Ozcan D. Primary lymphoma of the trigeminal nerve. British Journal of Neurosurgery 2006; 20(2): 103-5.

7. Descamps MJL. Primary sciatic nerve lymphoma: a case report and review of the literature. Journal of Neurology, Neurosurgery \& Psychiatry 2006; 77(9): 1087-9.

8. Kahraman S, Sabuncuoglu H, Gunhan O, Gurses MA, Sirin S. A rare reason of foot drop caused by primary diffuse large b-cell lymphoma of the sciatic nerve: case report. Acta Neurochir (Wien) 2009; 152(1): 125-8.

9. Okada M, Takamatsu K, Oebisu N, Nakamura H. Solitary neurolymphomatosis of the brachial plexus mimicking benign nerve sheath tumour: case report. British Journal of Neurosurgery 2012: 12.

10. Grisariu S, Avni B, Batchelor TT, et al. Neurolymphomatosis: an International Primary CNS Lymphoma Collaborative Group report. Blood 2010; 115(24): 5005-11.

11. Tomita $\mathrm{M}$, Koike $\mathrm{H}$, Kawagashira $\mathrm{Y}$, et al. Clinicopathological features of neuropathy associated with lymphoma. Brain 2013; 136(Pt 8): 2563-78.

12. Weerasuriya A, Mizisin AP. The Blood-Nerve Barrier: Structure and Functional Significance. 2011; 686: 149-73.

13. Eusebi V, Bondi A, Cancellieri A, Canedi L, Frizzera G. Primary malignant lymphoma of sciatic nerve. Report of a case. Am J Surg Pathol 1990; 14(9): 881-5.

14. Kim J, Kim YS, Lee EJ, Kang CS, Shim SI. Primary CD56-positive NK/T-cell lymphoma of median nerve: a case report. J Korean Med Sci 1998; 13(3): 331-3. 